
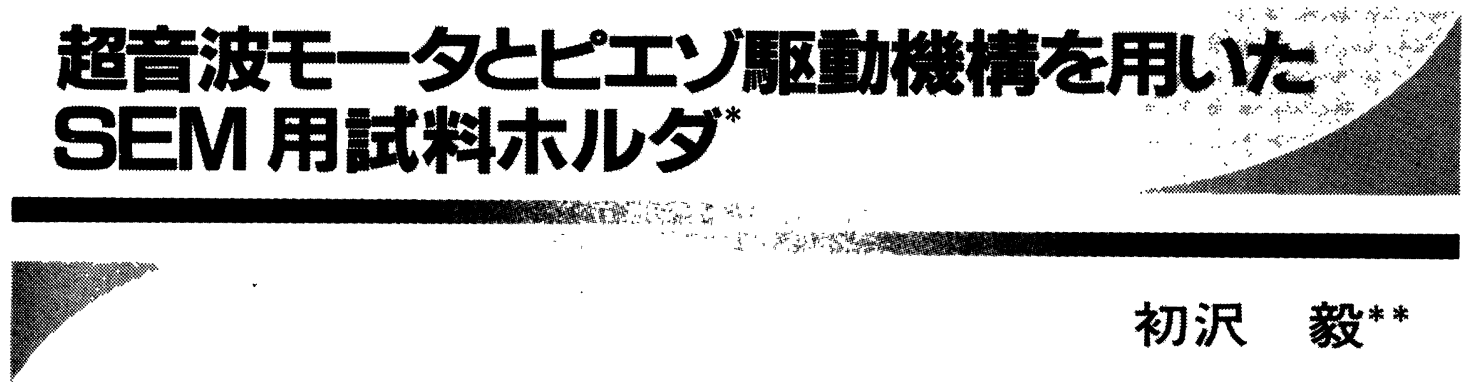

\title{
初沢 毅**
}

Key words : ultrasonic motor, piezodriven spindle, specimen holder, rotary table, inchworm mechanism, traveling wave, piezoelectric element

\section{1. はじめに}

走査型電子顕微鏡 (SEM) 真空試料室内で試料の姿 勢を調整するには，通常マイクロメータを用いた手動 マニピュレータが使用されているが，口ッドなどの機 械結合部分があるため室内での移動が制限をうける。 筆者らのグループはSEM をべースとした ICパター ンなどの絶対測定装置を開発中であり ${ }^{1)}$ ，外部からの 機械的な結合が無く，試料室内に自由に設置可能で角 度分解能 $1^{\circ}$ 程度をもつ試料姿勢变化機構が必要に なった。特に試料を保持しティルトを調整する $\phi$ 軸, 水平面内の回転を行ら $\theta$ 軸の機構については, 電子 ビームの直下に置かれるため, 軸の駆動源として既存 のモータなど磁気を帯びた機器を使用することができ ない、これは漏洩磁束が電子ビームを偏向し, 観測デー 夕に悪影響を及ぼすからである。そこで磁気を用いな いアクチュェータとして压電セラミックスに着目し， $\phi$ 軸については積層ピエゾ素子を用いた回転型イン チウォーム機構を開発, また $\theta$ 軸に は超音波モータを応用することによ り, 上記の要求を満足する試料ホル ダを製作した。

\section{2. $\phi$ 軸駆動 機 構}

図 1 は $\phi$ 軸駆動機構の構成で, 試 料を載せるための切欠きを持つスピ ンドルと，これに対して対称に配置 された 2 組のアクチュエータュニッ

* 原稿受付 昭和 62 年 1 月 25 日

** 計量研究所 (茨城県新治郡桜村梅園 $1-1-4)$

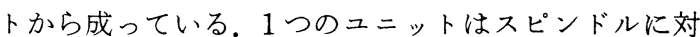
して上下動し，スピンドルの回転を拘束する（クラン プ動作）とともに前後にも動く（フィード動作）こと ができるように，ピェゾ素子とてこ機構を組み合わせ てある。ピェゾ素子は積層型のもので, $150 \mathrm{~V}$ かけたと き図中の長い方は $16 \mu \mathrm{m}$, 短い方は $7 \mu \mathrm{m}$ 程度伸縮す る。この伸縮量をそのまま本機構に用いると，スピン ドルークランプ部分の部品の工作精度が非常に厳しく なると同時に，フィード量が小さくなり回転が遅くな るので，板ばねによるてこ機構により変位を拡大して いる. 拡大量はフィード側が約 5 倍, クランプ側が 1.6 倍程度である。

スピンドルの回転は，(1)一方のニニットのクラン プ状態を解除し，他方をスピンドルに接触させる，(2) 接触側のユニットを前進すると摩擦によりスピンドル が回転する，（3）現状を維持するため他方をクランプ 状態にするとともに，送り動作をしたユニットのクラ ンプを解除する，（4）クランプしたユニットを前進す

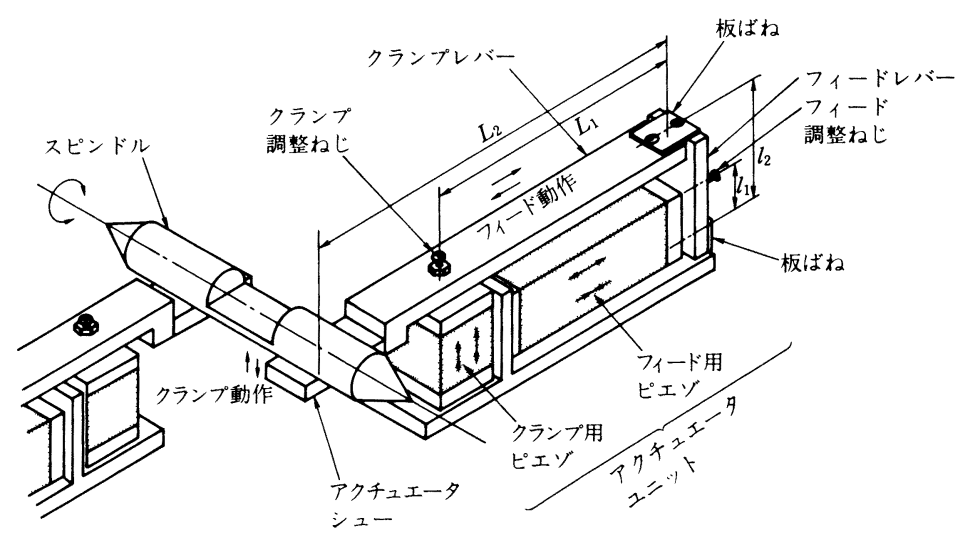

図 1 ピエゾ駆動機構の概略図 
ると同時にもら一方を後退させる，という4つのシー ケンスの繰返しにより行われる，回転の向きを変える にはアクチュエータを前後するタイミングをクランプ のタイミングに対して反転すればよい.

この機構による 1 ステップ当たりのフィード動作平 均送り量は, 駆動電圧 $150 \mathrm{~V}$ のとき $40 \mu \mathrm{m}$ であり, ス ピンドル直径が $6 \mathrm{~mm}$ なので回転角度では $7.6^{\prime \prime}$ に相 当する. 最高回転速度は, ドライブ周波数 $48 \mathrm{~Hz}$ のと き $38.3^{\circ} /$ 秒（1 回転当たり $9.4^{\prime \prime}$ ）であり，これ以上に なるとてこ部分の機械的な応答速度やスピンドルとの 接触部分のスリップロスが増大し, 回転速度は頭打ち 傾向になる，スピンドルの位置決めは，ロータリーエ ンコーダによる位置検出を用いて NC仕様になって 扣り, 位置決め角度分解能は $0.9^{\circ}(1 / 400$ 回転) が得ら れている2)3).

\section{3. $\theta$ 軸回転テーブル}

$\theta$ 軸回転テーブルの駆動要素として要求される仕様 は, 前述した磁気を用いない条件のほかに試料室のス ペース的な制約から極力薄型形状のものが必要になっ た。そこで指田により開発された超音波モータの一種 である回転型表面波モータ4)の採用を検討し，同モ一 タの速度制御特性を調べ，位置決め制御に最適な制御 パラメータを決定するとともに, 分解能 5.4'(1/4000 回転）の位置決め制御系が構成できることを確認し た5) 7).

このモータは, 環状のピェゾ素子により励振される ステータとダイヤフラム状のロータからなる。ロータは 加圧力調整ナットにより中心部を固定されるとともに 適当な圧力でステータに圧接され，図 2 に示したよう にステータ上に発生した進行波に対し波乗りをするよ らにして回転する。ステータの裏側にはピェゾ振動子 がエポキシ系接着剤で貼り付けられており，2相の高 周波電圧, $\cos \omega t$ 拈よび $\sin \omega t$ を印加する。それぞれ の励振により位相の異なる 2 つの定在波がステータ上 に生じ, この重ね合わせにより進行波が発生する。こ のような進行波発生のメカニズムをモデル化し, 超音 波モータの回転速度を制御するためのパラメータには

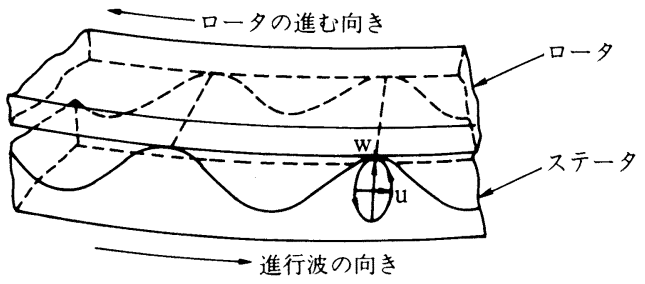

図 2 超音波モータの駆動原理図
どのようなものがあるかを理論的に検討した結果，2 つの励振源の振幅比 $B / A$, 位相差 $\phi$, 励振周波数 $f$ $(=\omega / 2 \pi)$ の 3 つのパラメータで制御できるというこ とがわかった。 これをもとに実験系を構成し一つ一つ のパラメータについて特性を調査した結果から，回転 テーブル駆動の制御を行らパラメータとして，スロー スタートが可能な励振周波数可変方式を用いるのが適 当であることが明らかになっだ) 7).

超音波モータを用いた $\theta$ 軸位置決め制御系は，口一 タリーエンコーダによる回転角度検出を用いた一般的 な構成である.コントローラとして 8087 数值演算プロ セサ付きの PC 9801 を用い，パラレル I/O ポートによ り入出力を行っている。制御には一般的な比例制御を 用いたが，回転テーブルへの使用が目的なので，急な 加速を避けるため，スタートからある時間内だけ等加 速を行らことができるようにスロースタートルーチン を組み込んだ。なおサンプリングタイムは $10 \mathrm{~ms}, 1$ サ ンプリング当たりの制御プログラムのオーバヘッドは 約 $120 \mu \mathrm{s}$ である。

超音波モータとピエゾ駆動機構の位置決めは同一の ソフトウェアで行っており，ドライバ部分のみをソフ トウェアの仕様に合わせて作成している。

\section{4. 全体の構成}

本ホルダは真空中で使用するためほとんどの部材に SUS 材を用いている。その㴗かの部分も接着剂からは んだ，電線に至るまですべてアウトガスが少なく，か つある程度の温度のベーキングに耐える部材を吟味し て使用している。これはSEM 使用時に測定試料表面 に付着するカーボンなどによる污染を低減するのが主 たる目的であるが，一般真空用機器に関しても清浄な 環境を保障するために非常に重要な検討事項である。

図 3 に本ホルダの組立図を示す，底部に超音波モー タを配置し，ここからシャフトを立ち上げ，ピェゾ駆 動機構が装備されている回転テーブルに結合されてい る。超音波モ一タのロータ上にはェンプラ製の平歯車 が固定されており，側方に設置されたロータリーエン コーダの軸を駆動し，位置情報を与えるようになって いる. シャフトを支觉ているベアリングには，真空用 に銀のイオンプレーティングが施されたものを用い た.

超音波モータと回転テーブルの間には，テーブル上 のピエゾ素子に電力を供給すると同時に $\phi$ 軸のロ一 タリーエンコーダの信号を伝送するための 10 極のス リップリングが設けられている。このスリップリング の円板は快削性のセラミックス板により製作されてお 


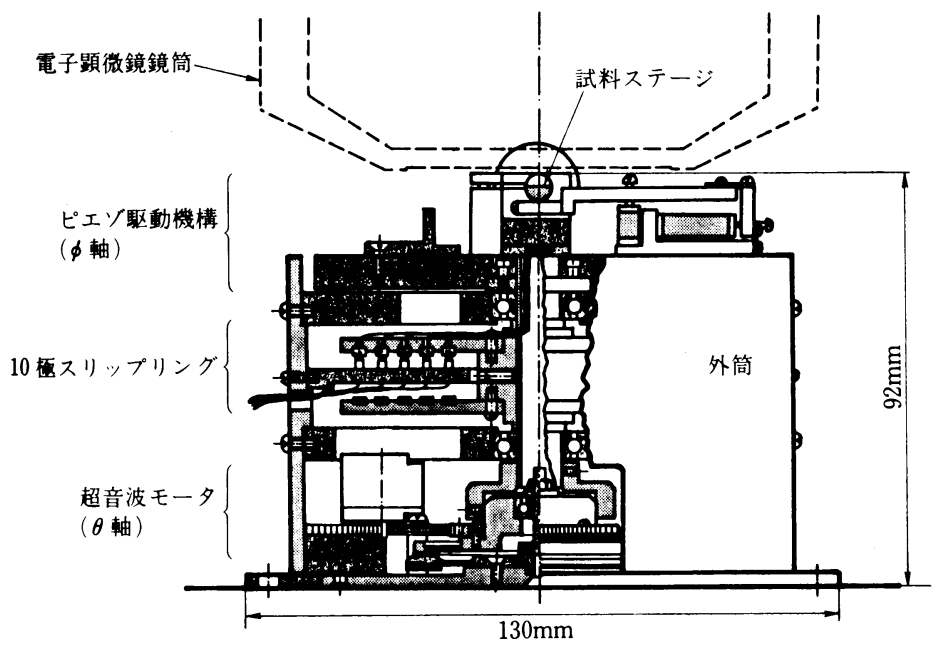

図 3 試料ホルダの組立図

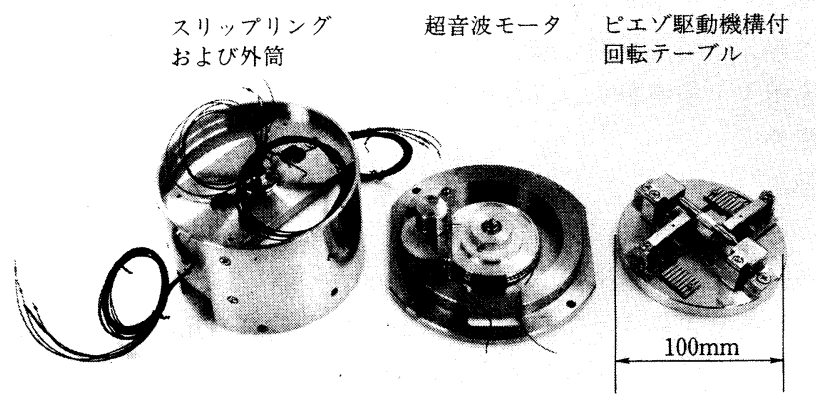

図 4 製作中の試料ホルダの写真

現在までのところ，空気中の動作 についてはすべて良好であることを 確認しており，テスト用真空チェン バの完成を待って本格的な性能試験 に入る予定である。, $\phi, \theta$ 軸とも摩擦 を駆動源としたものであるが, 真空 中では摩擦は増大方向に働くので所 期の性能を発揮してくれるものと確 信している.

\section{5. おわりに}

SEM 真空試料室で使用する試料 姿勢制御機構について述べた。この ような装置の製作においては，環境 を污染しない材料の選定作業がかな りのウェイトを占め, 日常当然のよ らに使用している電子部品や機械材 料が使光ず，思わ好苦労をすること が多い，最近ではさまざまな新材料 が出回っており，これらを用いて一 層の性能向上を図っていきたい。

\section{参 考 文 献}

1）豊田幸司ほか：微細形状のナノメー トル計測技術, 計測と制御, 25,5 (1986) 417

2) T. Hatsuzawa et al.: Piezodriven Spindle for a Specimen Holder in the Vacuum Chamber of a Scanning Electron Microscope, Rev. Sci. Instrum., 57, 12, (1986) 3110.

り,電極部分は金めっきされた銅合金を使用している. ロータリーエンコーダは $\phi, \theta$ 軸とも 1 回転当たり 300 パルスのものを用いているが，市販のものから目盛板 だけ取り出し，ヶーシングはステンレスで作り直して ある。

摩擦部分の摩耗については, 超音波モータはしゅう 動面にポリイミドアミドがコーティングされており, まず問題はないと考えられる。 またピエゾ駆動機構に ついては，スピンドルと接触するシューの部分を取換 え可能なチップ状に製作してあり，適宜交換すること

3）初沢毅 と位置決め制御, 第 25 回計測自動制御学会学術講演会予 稿集, JS 53-2 (1986) 581.

4）指田年生：超音波乇一夕，応用物理， 54，6（1985） 589 .

5）初沢 毅ほか：ピエゾ駆動機構を用いた試料ホルダー, 第 47 回応用物理学会学術講演会講演予稿集, $28 \mathrm{a}-\mathrm{Y}-6,35$ (1986).

6) T. Hatsuzawa et al.: Speed Control Characteristics and Digital Servosystem of a Circular Traveling Wave Motor, Rev. Sci. Instrum., 57, 11, (1986) 2886.

7）初沢 毅：超音波乇一夕の位置決め制御系, 計測技術, 15, 2 (1987) 35 .

により対処することにしている. 